pathogenesis of PH associated with SCD. The roles of IL 8 and SCF warrant further investigation.

\section{P36 FUNCTIONAL CLASS AND GAS TRANSFER ARE USEFUL TOOLS IN THE ASSESSMENT OF PULMONARY HYPERTENSION ASSOCIATED WITH SICKLE CELL DISEASE}

doi:10.1136/thx.2010.150961.36

${ }^{1} \mathrm{H}$ Ranu, ${ }^{2} \mathrm{~L}$ Brown, ${ }^{2} \mathrm{~J}$ Lee, ${ }^{1} \mathrm{BP}$ Madden. ${ }^{1} S t$ George's Hospital, London, UK; ${ }^{2} \mathrm{St}$ George's Medical School, Loondon, UK

Introduction and Objectives WHO Functional class (FC) is an important tool in the management of patients with pulmonary arterial hypertension. There is an increasing awareness of pulmonary hypertension $(\mathrm{PH})$ as a complication of Sickle cell disease (SCD). We wished to evaluate functional class and gas transfer (diffusion capacity DLCOc, KCOc) in patients with SCD (HbSS) with and without $\mathrm{PH}$ based on trans thoracic echocardiogram.

Methods 32 patients were reviewed and their functional class was determined. Trans thoracic echocardiograms were reviewed in these patients for evidence of $\mathrm{PH}$ (defined as a tricuspid regurgitation jet velocity $T R V \geq 2.5 \mathrm{~m} / \mathrm{s}$ ). Haematological and lung function data were also reviewed. Only patients in steady state and without a crisis in the preceding 2 weeks were included.

Results Of patients with $\mathrm{PH} 36 \%(5 / 14)$ were FC $\geq 3$ compared to $6 \%(1 / 18)$ without PH. There was a significant difference in functional class in patients with and without $\mathrm{PH}$ on echocardiogram $(p<0.05)$. There was a significant correlation between TRV and WHO functional class $(\mathrm{p}=0.002, \mathrm{r}=0.54)$. The correlation between TRV and functional class remained significant after correction for haemoglobin. Mean haemoglobin was $8.3 \pm 1.3 \mathrm{~g} / \mathrm{dl}$ in those with $\mathrm{PH}$ and $10.1 \pm 1.4 \mathrm{~g} / \mathrm{dl}$ in those without $\mathrm{PH}(\mathrm{p}=0.001)$. Neither $\mathrm{PH}$ nor FC was associated with parenchymal abnormalities visible on CT and/or chest radiograph. $\mathrm{PH}$ was also associated with a lower diffusion capacity (DLCOc $\mathrm{mmol} / \mathrm{min} / \mathrm{kPa}: 3.60 \pm 0.79$ vs $7.60 \pm 2.66, p=0.034)$ and a lower diffusion capacity corrected for alveolar volume (KCOc $\mathrm{mmol} / \mathrm{min} / \mathrm{kPa} / \mathrm{l}: 1.04 \pm 0.31$ vs $1.96 \pm 0.3$, $\mathrm{p}=0.034)$. TRV was significantly correlated with DLCOc only $(\mathrm{p}=0.036 \mathrm{r}=-0.79)$.

Conclusion Although patients with Sickle cell disease may have a number of reasons to account for their breathlessness, functional class and measurements of gas transfer may be useful markers in screening patients for pulmonary hypertension regardless of low steady state anaemia.

\section{P37 FLYING - SAFER THAN WE THOUGHT? A QUESTIONNAIRE- BASED STUDY OF 156 INDIVIDUALS WITH HEREDITARY HAEMORRHAGIC TELANGIECTASIA; 95 WITH PULMONARY AVMS}

doi:10.1136/thx.2010.150961.37

${ }^{1}$ CG Mason, ${ }^{2} \mathrm{CL}$ Shovlin. ${ }^{1}$ Imperial College Healthcare NHS Trust, London, UK; ${ }^{2} \mathrm{NHLI}$, Imperial College London, London, UK

Introduction Flight has become an integral part of modern life: 65.9 million passengers used Heathrow airport in 2009. ${ }^{1}$ Flight, however, exposes us to a unique environment with a reduced $\mathrm{FiO}_{2-}$, increased humidity and relative immobility. Although guidelines have been published, ${ }^{2}$ there are relatively limited published data regarding flight safety. Patients with particular conditions may provide high risk models for the general population regarding the safety of the flight environment. Here we report the results of a questionnairebased study in individuals with hereditary haemorrhagic telangiectasia (HHT), a condition that leads to recurrent nosebleeds, but more importantly for respiratory physicians, frequent pulmonary arteriovenous malformations (PAVMs) that result in a right to left shunt, hypoxaemia, and risk of paradoxical embolic stroke. ${ }^{3}$

Methods PubMed searches identified no studies into the effect of flight in HHT or PAVM patients. With ethical approval (NRES 10/ H0806/8), patients with definite HHT who had attended our hospital's HHT clinic, were sent a questionnaire. Participants were asked to document flights they had taken, and to list any symptoms they experienced during or shortly afterwards. Responses were correlated with physiological variables in their hospital records.

Results 156 replies were received from 308 questionnaires (response rate 50.6\%). 145 individuals (95 [65\%] with pulmonary AVMs), had flown, reporting 18943 flight hours in 3950 flights. The median number of flights per patient was 17 short haul, and 8 long haul. There was no difference in erect $\mathrm{SaO}_{2}$ between those who reported breathlessness and those who did not (median 93 (range 85-96)\% vs median 94 (84-99)\% respectively. Individuals who reported breathlessness stated that in-flight oxygen was of benefit (Abstract P37 Table 1).

Abstract P37 Table 1 All six patients reporting dyspnoea had PAVMs

\begin{tabular}{|c|c|c|c|c|c|}
\hline & Asymptomatic & Nosebleed & Dyspnoea & $\begin{array}{l}\text { Deep } \\
\text { venous } \\
\text { thrombosis }\end{array}$ & $\begin{array}{l}\text { Ischaemic } \\
\text { Stroke }\end{array}$ \\
\hline \multicolumn{6}{|l|}{ All flights } \\
\hline Patients (n (\%)) & $111(77)$ & $26(18)$ & $6(4)$ & $2(1)$ & $1(<1)$ \\
\hline \multicolumn{6}{|l|}{ Short haul $(<6 \mathrm{~h})$} \\
\hline Patients (n (\%)) & $130(89)$ & $14(10)$ & $3(2.1)$ & $0(0)$ & $0(0)$ \\
\hline Flights taken (n (\%)) & $2864(96)$ & $78(3)$ & $39(1)$ & $0(0)$ & $0(0)$ \\
\hline \multicolumn{6}{|c|}{ Long haul ( $\geq 6 \mathrm{~h}$ ) } \\
\hline Patients (n (\%)) & $120(83)$ & $20(14)$ & $6(4)$ & $2(1.4)$ & $1(0.7)$ \\
\hline Flights taken (n (\%)) & $837(86)$ & $112(12)$ & $17(2)$ & $2(<1)$ & $1(<1)$ \\
\hline
\end{tabular}

Conclusion These data suggest that even in a population group expected to be more susceptible to complications, flying appeared safe for the vast majority of individuals. A minority of HHT patients did experience adverse symptoms. These were difficult to predict based on clinic measurements.

\section{REFERENCES}

1. http://www.heathrowairport.com.

2. Managing Passengers with Respiratory Disease Planning Air Travel. British Thoracic Society Standards of Care Committee, 2004.

3. Govani FS, Shovlin CL. Hereditary haemorrhagic telangiectasia: a clinical and scientific review. Eur J Hum Genet 2009:17:860-71.

\section{P38 WHICH PATIENTS WITH PULMONARY ARTERIOVENOUS MALFORMATIONS ARE DYSPNOEIC? RETROSPECTIVE ANALYSIS OF A SINGLE CENTRE 2005-2010 COHORT}

doi:10.1136/thx.2010.150961.38

${ }^{1} \mathrm{~V}$ Santhirapala, ${ }^{2} \mathrm{JT}$ Springett, ${ }^{2} \mathrm{H}$ Wolfenden, ${ }^{2} \mathrm{HC}$ Tighe, ${ }^{1} \mathrm{CL}$ Shovlin. ${ }^{1} / m p e r i a l$ College London, London, UK; ${ }^{2}$ Imperial College Healthcare NHS Trust, London, UK

Introduction/objectives Pulmonary arteriovenous malformations (PAVMs) are aberrant connections between pulmonary arteries and veins, creating a right-to-left shunt. Hypoxaemia is common, ${ }^{1}$ but dyspnoea is usually not the presenting complaint. ${ }^{2}$ We hypothesised this may be relevant to dyspnoea mechanisms in the general population.

Methods With ethical approval, new patients presenting with CTproven PAVMs between June 2005 and July 2010 were studied retrospectively. Based on self-reported exercise tolerance at presentation, and blinded to physiological measurements, two 
investigators assigned patients to the MRC dyspnoea scale, grading dyspnoea on strenuous exertion only (normal, Grade 1); on incline/ stairs (2); and on the level (3-5 according to severity). Individuals undertaking regular/intense sport were reclassified as Grade ' 0 '. Four separate $\mathrm{SpO}_{2}$ measurements, after standing for 7, 8, 9 and $10 \mathrm{~min}$, were used for statistical calculations using GraphPad software. Interim analyses were performed on the first 88 patients.

Results In the absence of severe pulmonary hypertension or emphysema, only $18 \%$ of patients were dyspnoeic (Abstract P38 Table 1). To determine which factors might influence dyspnoea, single variables were examined. There was considerable overlap in the $\mathrm{SpO}_{2}$ values between the three groups of Grade ' 0 ', 1 and 2, and no relationship between dyspnoea grade and $\mathrm{SpO}_{2}$ demonstrated by Spearman's rank correlation coefficient $(r=0.09 ; \mathrm{p}=0.39)$. The patients however, ranged in age from 17 to 87 years, and older patients were more dyspnoeic (Spearman $\mathrm{r}=0.33$; $\mathrm{p}=0.0016$ ). Multiple regression analyses were therefore performed to determine whether there was a relationship between $\mathrm{SpO}_{2}$ and dyspnoea that was masked by differences in age. These suggested $\mathrm{SpO}_{2}$ may make an independent contribution to dyspnoea $(p=0.064)$, although age was still more strongly associated $(p=0.0044)$. However, these factors alone did not account for most of the population variation in dyspnoea grade (overall model: $r^{2}=11.37 \%, p=0.0073$ ).

Abstract P38 Table 1 Population stratification by dyspnoea grade: ${ }^{*}$ Quartile distribution $(01,02,03)$ where 02 represents the median value

\begin{tabular}{lllll}
\hline $\begin{array}{l}\text { MRC } \\
\text { grade }\end{array}$ & $\begin{array}{l}\text { Number } \\
\text { of cases }\end{array}$ & $\begin{array}{l}\text { Sp02 }(\%) \\
\text { range }\end{array}$ & $\begin{array}{l}\text { Sp02 (\%) } \\
\text { quartiles* }\end{array}$ & $\begin{array}{l}\text { Corrected* } \\
\text { number (\%) }\end{array}$ \\
\hline “0” & 19 & $78.5-99$ & $90.7,94.5,96.2$ & $19(22)$ \\
1 & 51 & $83.5-98$ & $93.6,95.5,96.5$ & $51(60)$ \\
2 & 15 & $80.8-98$ & $85.6,90.5,93.1$ & $15(18)$ \\
3 & 2 & $89-92.5$ & $89.1,89.2,90.8$ & 0 \\
4 & 1 & $95-95$ & $95.0,95.0,95.0$ & 0 \\
5 & 0 & - & - & 0 \\
\hline
\end{tabular}

*Excludes patients with severe pulmonary hypertension $(\mathrm{n}=2)$, or severe emphysema $(n=1)$.

Summary These data imply that it is unusual for PAVMs alone to account for moderate to severe dyspnoea, and that there is less of an influence of $\mathrm{SpO}_{2}$ than expected. Further study is warranted.

\section{REFERENCES}

1. Shovlin CL, Jackson JE, eds. Murray and Nadel's textbook of respiratory medicine. 5th edn, 2010, pp. 1261-82.

2. Shovlin, et al. Thorax 2008;63:259-66.

\section{P39 PULMONARY HYPERTENSION (PH) ASSOCIATED WITH LUNG DISEASE/ HYPOXIA}

doi:10.1136/thx.2010.150961.39

J Hurdman, R A Condliffe, C A Elliot, I Sabroe, D G Kiely. Sheffield Pulmonary Vascular Disease Unit, Royal Hallamshire Hospital, Sheffield, UK

Background Mild elevation in pulmonary artery pressure (PAP) is common in patients with lung disease. In COPD, 2 groups are defined; $\mathrm{PH}$ proportionate to degree of underlying lung disease and $\mathrm{PH}$ out of proportion (mPAP $\geq 40 \mathrm{~mm} \mathrm{Hg}$ ) occurring in a minority. Aim To characterise survival and prognostic factors in patients with $\mathrm{PH}$ associated with lung disease.

Methods Single centre retrospective review of cardiac catheters performed 2001-2010 identified incident cases of $\mathrm{PH}$ associated with lung disease.

Results 155 patients had a primary diagnosis of $\mathrm{PH}$ associated with lung disease, 96 with COPD (57 PH out of proportion to COPD, 39
$\mathrm{PH}$ proportionate to $\mathrm{COPD}), 31 \mathrm{PH}$ in interstitial lung disease $(\mathrm{PH}-$ ILD) and $28 \mathrm{PH}$ with sleep disordered breathing / alveolar hypoventilation. Survival is shown in Abstract P39 Figure 1. Right heart pressures were most raised in patients with $\mathrm{PH}$ out of proportion to COPD compared to $\mathrm{PH}-\mathrm{ILD}$ and $\mathrm{PH}$ in proportion to COPD with mRAP 12.3, 8.5 and $8.2 \mathrm{~mm} \mathrm{Hg}(\mathrm{p}<0.05)$ and mPAP 49.4, 38.6 and $32.3 \mathrm{~mm} \mathrm{Hg}(\mathrm{p}<0.01)$ respectively. In patients with $\mathrm{PH}$ associated with sleep disordered breathing/alveolar hypoventilation mRAP was 11.6 and mPAP $37.8 \mathrm{~mm} \mathrm{Hg}$. Cardiac index and PVR were similar in $\mathrm{PH}$ out of proportion to COPD and PH-ILD but markedly reduced in both groups when compared to $\mathrm{PH}$ in proportion to COPD $(p<0.01)$. Baseline shuttle walking distance was most reduced in $\mathrm{PH}$ out of proportion to COPD with mean $67 \mathrm{~m}$ compared to $133 \mathrm{~m}$ in PH-ILD and $156 \mathrm{~m}$ in $\mathrm{PH}$ in proportion to COPD $(\mathrm{p}<0.05)$. In COPD, airflow obstruction was less severe in patients with out of proportion $\mathrm{PH}$ than COPD with proportionate $\mathrm{PH}\left(\mathrm{FEV}_{1} 63 \%\right.$ vs $51 \%$ respectively) but TLCO was more severely affected (26\% vs $38 \%)$.

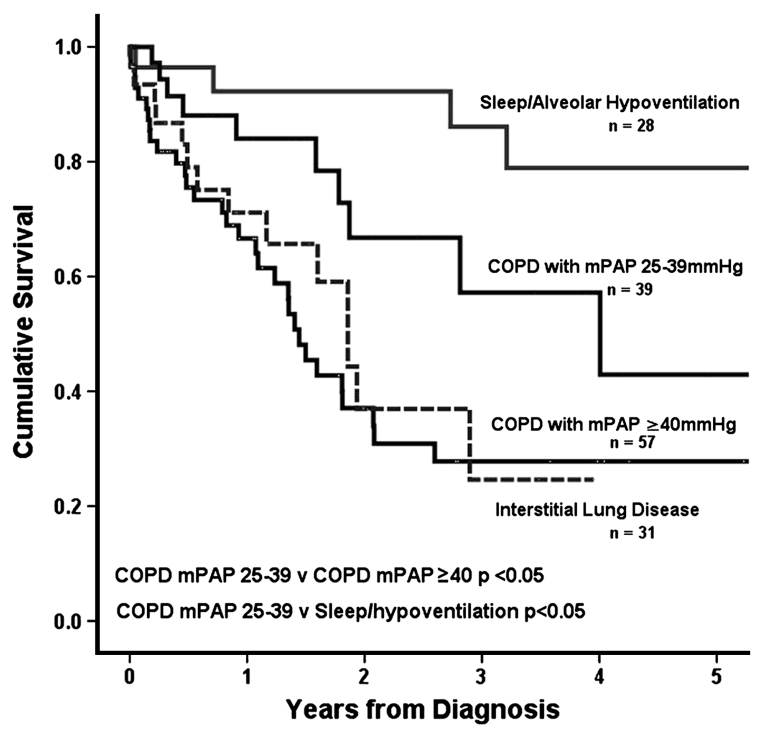

Abstract P39 Figure 1 Cumulative survival from diagnosis in patients with pulmonary hypertension associated with respiratory disease.

Conclusions The survival of patients with $\mathrm{PH}$ in association with lung disease is dependent on the underlying aetiology. Whereas patients with $\mathrm{PH}$ associated with sleep disordered breathing/alveolar hypoventilation have a good prognosis, patients with $\mathrm{PH}$ in the setting of ILD and PH out of proportion to COPD have a poor prognosis

\section{P40 A COMPARISON OF THE VALUE OF OXYGEN SHUNT STUDIES AND CARDIAC BUBBLE ECHO AS SCREENING TOOLS FOR PULMONARY ARTERIOVENOUS MALFORMATIONS IN PATIENTS WITH SUSPECTED HEREDITARY HAEMORRHAGIC TELANGIECTASIA}

doi:10.1136/thx.2010.150961.40

JW Donaldson, K Pointon, T Mathew, AW Fogarty. Nottingham City Hospital, Nottingham, UK

Hereditary haemorrhagic telangiectasia (HHT) is an autosomal dominant genetic disorder associated with recurrent spontaneous epistaxis, mucocutaneous telangiectasia and visceral arteriovenous malformations (AVMs). Up to $30 \%$ of patients with HHT have pulmonary AVMs (PAVMs) which are associated with an increased 